\title{
Gangguan Kognitif terhadap Resiko Terjadinya Jatuh Pada Lansia
}

\author{
Enggong Eni ${ }^{1}$, Aisyah Safitri ${ }^{2}$ \\ ${ }^{1,2}$ Program Studi Sarjana Ilmu Keperawatan \\ Sekolah Tinggi Ilmu Kesehatan Indonesia Maju \\ Jln. Harapan Nomor 50, Lenteng Agung - Jakarta Selatan 12610 \\ Telp.(021)78894045 Email : 1'enggongenny@yahoo.com, ${ }^{2}$ aisyirfan12@yahoo.com
}

\begin{abstract}
Abstrak
Permasalahan yang terjadi pada lansia adalah terjadinya proses menua dimana kondisi lansia akan mengalami perubahan multipatologi, masalah kesehatan, nutrisi, gangguan kognitif dan resiko jatuh. Tujuan dalam penelitian ini adalah untuk mengetahui hubungan gangguan kognitif terhadap resiko terjadinya jatuh. Metode yang digunakan adalah deskriptif korelasi dengan desain cross sectional yaitu mempelajari faktor analisa antara gangguan kognitif terhada resiko jatuh, dengan cara wawancara dan pengkajian. Populasi dalam penelitian ini adalah semua lansia yang mengalami masalah gangguan kognitif di panti sosial tresna werdha. Sampel penelitian ini adalah semua lansia yang mengalami gangguan kognitif sedang dan berat di seluruh ruangan. Teknik pengambilan sampel menggunakan total sampling. Dari hasil penelitian menunjukan bahwa usia lansia terbanyak usia 75-90 tahun, dan responden terbanyak berjenis kelamin wanita, sedangkan gangguan kognitif terbanyak terdapat pada lansia dengan gangguan kognitif berat, dan resiko jatuh rendah. Dari hasil pengolahan data mengunakan uji Corelasi dengan tingkat signifikan $=907$ hasil dari penelitian ini menunjukan terdapat hubungan erat antara gangguan kognitif dengan resiko jatuh. Upaya yang harus di tingkatkan adalah meningkatkan mutu pelayanan terhadap lansia memberikan penyuluhan, menguji terapi aktivitas kelompok, pengkajian aspek kognitif mental seperti orientasi, registrasi, perhatian, mengingat dan bahasa.
\end{abstract}

Kata kunci : Lansia, gangguan kognitif dan resiko jatuh

\begin{abstract}
Problems that occur in the elderly is the aging process where the condition of the elderly will be amended multipatologi, health, nutrition, cognitive disorders and the risk of falling. The purpose of this research was to determine the relationship of cognitive impairment against the risk of falling. The method used is descriptive correlation with cross sectional design which is studying the factors analysis between cognitive impairment terhada the risk of falls, by interview and assessment. The population in this study were all elderly who have problems of cognitive impairment in social institutions tresna Werdha. Samples were all elderly who have moderate and severe cognitive impairment in rooms. The sampling technique using total sampling. From the results of the research shows that most elderly age of 75-90 years, and most respondents are female, whereas most cohnitive disorders are found in elderly with severe cognitive impairment, and the risk of falling low. From result of data processing using correlation test with significan level $=907$ the results of this study pointed to a close relationship between cognitive impairment and falling risk, relationship of cognitive impairment against the risk of fall. The efforts should be improved is to improve the quality of service to the elderly to provide counseling, testing the therapy group activities, assessment of cognitive mental aspects such as orientation, registration, attention, recall and language.
\end{abstract}

Keywords : Elderly, cognitive disorders and the risk of falls 


\section{Pendahuluan}

Lanjut usia adalah bagian dari proses tumbuh kembang. Manusia tidak secara tibatiba menjadi tua, tetapi berkembang dari bayi, anak-anak, dewasa dan akhirnya menjadi tua. Hal ini normal, dengan perubahan fisik dan tingkah laku yang dapat diramalkan yang terjadi pada semua orang pada saat mereka mencapai usia tahap perkembangan kronologi tertentu. Lansia merupakan suatu proses alami dimasa ini seorang mengalami kemunduran fisik, mental dan sosial secara bertahap. ${ }^{1}$

Golongan usia pada lansia dibagi dalam 4 kategori diantaranya yaitu usia pertengahan (middle age) adalah usia 45-59 tahun, usia lanjut (eldery) adalah 60-74 tahun, lanjut usia tua (old) adalah 75-90 tahun, dan usia sangat tua (very old) diatas 90 tahun. $^{2}$

Masalah yang berkaitan dengan perkembangan kehidupan lansia salah satunya adalah proses menua, baik secara fisik, mental maupun psikososial. Semakin lanjut usia seseorang, maka kemampuan fisiknya akan semakin menurun, sehingga dapat mengakibatkan kemunduran pada peran-peran sosialnya. Hal ini mengakibatkan pula timbulnya gangguan dalam mencukupi kebutuhan hidupnya, hingga dapat Meningkatkan ketergantungan yang memerlukan bantuan orang lain. Salah satunya adalah gangguan kesehatan yang muncul pada lansia adalah gangguan mental. ${ }^{3}$

Gangguan kognitif adalah kemampuan pengenalan dan penafsiaran seseorang terhadap lingkungannya berupa perhatian, bahasa, memori, visuospasial dan fungsi memutuskan. Lansia yang mengalami gangguan kognitif awalnya ditemukan gejala mudah lupa yang menyebabkan lansia tidak mampu menyebut kata yang benar, berlanjut dengan kesulitan mengenal benda dan akhirnya tidak mampu menggunakan barang-barang sekalipun yang termudah. ${ }^{4}$

Gejala gangguan kognitif ini dapat diikuti gangguan perilaku seperti: waham curiga, halusinasi pendengaran atau penglihatan, agitasi (gelisah, mengacau), depresi, gangguan tidur dan nafsu makan. Gejalanya antara lain, disorientasi, gangguan bahasa (afasia), penderita mudah bingung, penurunan fungsi memori lebih berat sehingga lansia tidak dapat melakukan kegiatan sampai selesai, tidak mengenal anggota keluarganya dan tidak dapat mengingat tindakan yang sudah dilakukan sehingga dapat mengulanginya lagi. Selain itu penderita dapat mengalami gangguan visuospasial, menyebabkan penderita mudah tersesat di lingkungannya. Hal ini diperberat dengan kondisi lansia yang mengalami kemunduran kapasitas fisiologis, misalnya kekuatan otot, kapasitas aerobik, koordinasi neuromotorik, dan fleksibilitas sehingga lansia tersebut memiliki risiko terhadap cedera seperti terjatuh saat melakukan aktivitas fisik yang terbatas. ${ }^{5}$

Menurut penelitian terkait gangguan kognitif ringan di dapatkan hasil penelitian jumlah penduduk dengan gangguan kognitif ringan adalah $76,8 / 1000$ penduduk. ${ }^{6}$ Gambaran tingkat kognitif dan penurunan fungsi intelektual pada lansia, didapatkan hasil penelitian bahwa kerusakan kognitif sedang (59\%), kerusakan kognitif berat $(28,9 \%)$, penurunan fungsi intelektual sedang (53\%), dan penurunan fungsi intelektual ringan $(13,25 \%)^{7}$

Hubungan gangguan kognitif terhadap terjadinya injuri, didapatkan 18 orang lansia yang mengalami gangguan kognitif sedang, dan yang mengalami gangguan kognitif berat 27 orang, dan riwayat terjadinya injuri 18 orang termasuk lansia yang mengalami gangguan kognitf sedang dan berat. ${ }^{8}$

Faktor resiko penyebab gangguan kognitif disebabkan oleh beberapa faktor yaitu faktor usia, gender, ras, genetik, tekanan darah, payah jantung, aritmi jantung, diabetes militus, kadar lipid dan kolesterol, fungsi tiroid, alkohol, obesitas, merokok dan trauma. Faktor yang mempengaruhi fungsi gangguan kognitif. Faktor resiko yang dapat menyebabkan gangguan kognitif antara lain seperti : cedera kepala, obat-obatan toksik, infeksi susunan saraf pusat, epilepsi, dan penyakit serebrovaskular, tumor otak, dan degenerasi.. ${ }^{9}$

Dampak dari gangguan kognitif pada lansia akan menyebabkan bergesernya peran lansia dalam intreaksi sosial di masyarakat maupun dalam keluarga. Hal ini di dukung oleh sikap lansia yang cendrung egois dan enggan mendengarkan pendapat orang lain, sehingga akan menyebabkan lansia merasa terasing secara sosial yang pada akhirnya merasa terisolir dan merasa tidak berguna. ${ }^{10}$

Akibat gangguan kognitif berlanjut jika tidak segera ditangani (1) Menurun kemampuan konsentrasi terhadap stimulus 
(misalnya, pertanyaan harus diulang). (2) Proses pikir yang tidak tertata, misalnya tidak relevan atau inkoheren. (3) Menurun aktivitas psikomotor, jatuh pada lansia disebabkan oleh beberapa faktor seperti gangguan penglihatan dan pendengaran, perubahan fungsi neuromuskuler, kecelakaan, nyeri kepala atau vertigo, obat-obatan yang diminum, pemakaian alat bantu ambulasi yang tidak tepat, dan lingkungan yang licin, kurang perangan, disorientasi, tempat, waktu, orang, Gangguan daya ingat, tidak dapat mengingat hal baru, misalnya nama beberapa benda. Berdasar survai di masyarakat AS. ${ }^{1}$ mendapatkan sekitar $30 \%$ lansia umur lebih dari 65 tahun mengalami jatuh setiap tahunnya, separuh dari angka tersebut mengalami jatuh berulang. berkisar $1 / 3$ populasi lansia setiap tahun, dengan rata-rata jatuh $0,6 /$ orang. $5 \%$ dari penderita jatuh ini mengalami patah tulang atau memerlukan perawatan di rumah sakit. ${ }^{11}$

Upaya yang sudah dilakukan pada lansia yang mengalami gangguan kognitif yaitu, meningkatkan fungsi kognitif pada lansia adalah seperti terapi aktivitas kelompok dengan terapi Reminiscene, karena lansia akan mengunakan masa lalunya untuk mempertahankan pendapat dan kritik. ${ }^{12}$ Selain itu juga dengan tehnik Brain Gym atau senam otak / olahraga senam otak tidak saja merasang memperlancar aliran darah tetapi juga merangsang kedua otak untuk bekerja. ${ }^{13}$

Menguji aspek kognitif dari fungsi kognitif mental dengan menggunakan MMSE (mini mental state examination) meliputi : orientasi, registrasi, perhatian dan kalkulasi, mengingat kembali, dan bahasa. Upaya yang sudah dilakukan diatas masih belum maksimal dan diinginkan untuk tindakan intervensi berlanjut dikarenakan semakin bertambahnya jumlah lansia disetiap tahunnya maka kemungkinan lansia akan semakin banyak yang mengalami masalah dan gangguan kognitif. 14

Berdasarkan pengkajian yang dilakukan peneliti pada tanggal 3 Agustus 2015, di Panti Sosial Tresna Werdha Budi Mulya 4 Margaguna Jakarta Selatan, didapatkan jumlah 20 orang lansia yang mengalami gangguan kognitif sedang, dan 31 orang lansia yang mengalami gangguan kognitif berat. Oleh karena itu, peneliti ingin mengkaji lebih lanjut tentang keterkaitan hubungan gangguan kognitif terhadap terjadinya jatuh di Panti Sosial Tresna Werdha Budi Mulya 4
Margaguna Jakarta. Berdasarkan masalah di atas maka penulis tertarik untuk melakukan penelitian lebih lanjut dengan judul "Hubungan Gangguan Kognitif Terhadap Terjadinya Jatuh pada Lanjut Usia di Panti Sosial Tresna Werdha Budi Mulya 4 Margaguna Jakarta.

Permasalahan yang terjadi pada lansia adalah terjadinya proses menuan dimana kondisi lansia tersebut akan mengalami perubahan multipatologi menurunnya daya biologis, berubahnya gejala dan dan tanda penyakit dari yang klasik, terganggunya status fungsional lansia dan sering terjadi masalah gangguan nutrisi gizi kurang atau buruk. Salah satu nya terganggunya status fungsional yang paling menonjol adalah penurunan fungsi kognitif. Salah satu dampak dari gangguan kognitif adalah menurunya tingkat psikomotor koordinasi neuromotorik dan fleksibilitas sehingga lansia tersebut memiliki resiko terhadap cedera seperti jatuh saat berjalan dan melakukan aktivitas fisik yang terbatas. Berdasarkan data diatas maka dapat dirumuskan pertanyaan penelitian yaitu "Bagaimanakah hubungan gangguan kognitif terhadap resiko terjadinya jatuh pada lansia. ${ }^{15}$

Tujuan penelitian ini secara umum bertujua untuk mengetahui Hubungan Gangguan Kognitif Terhadap Terjadinya Jatuh pada Lanjut Usia di Panti Sosial Tresna Werdha Budi Mulya 4 Margaguna Jakarta. Tujuan Khusus Secara khusus penelitian ini bertujuan untuk : Memberikan gambaran mengenai krakteristik lansia, Mengetahui masalah lansia yang mengalami gangguan kognitif di Panti Sosial Tresna Werdha Budi Mulya 4 Margaguna Jakarta. Mengetahui jumlah lansia yang mengalami jatuh di Panti Sosial Tresna Werdha Budi Mulya 4 Margaguna Jakarta. Mengetahui hubungan gangguan kognitif dengan terjadinya jatuh pada lansia di Panti Sosial Tresna Werdha Budi Mulya 4 Margaguna Jakarta.

\section{Metode}

Metode yang digunakan dalam penelitian ini adalah metode deskriptif korelasi dengan desain cross sectional. Untuk mengetahui gangguan kognitif dengan resiko terjadinya jatuh, menggunakan format pengkajian mini mental state examination untuk mengukur aspek kognitif orientasi, registrasi, perhatian, kalkulasi dan bahasa. ${ }^{16}$ 
Populasi dalam penelitian ini adalah semua lansia yang mengalami masalah gangguan kognitif dan beresiko terjadinya jatuh di Panti Sosial Tresna Werdha Budi Mulya 4 Margaguna Jakarta yang berjumlah 51 responden lansia. yang di ambil secara total sampling dimana semua unsur yang ada dipopulasi mempunyai peluang yang sama untuk diambil sebagai sampel sesuai dengan jumlah lansia yang mengalami masalah gangguan kognitif dan resiko jatuh. Sampel dalam penelitian ini yaitu 51 responden yang diambil secara total total sampel. Teknik pengambilan sampel melalui orang yang dianggap paling tahu tentang masalah gangguan kognitif pada lansia di tempat tersebut sehingga akan memudahkan peneliti memilah lansia yang akan di jadikan sampel penelitian di Panti Sosial Tresna Werdha Budi Mulya 4 Margaguna Jakarta. ${ }^{17}$

Tempat penelitian yang digunakan oleh peneliti adalah Panti Tresna Werdha Budi Mulya 4 Margaguna Jakarta. Dimana lansia dengan gangguan kognitif dan resiko terjadinya jatuh dapat ditemukan di 7 ruangan yaitu ruangan kutilang, cendrawasih, cempaka, anggrek, mawar, kenanga dan melati. Waktu waktu penelitian dilakukan pada bulan agustus 2015 - dari mulai penyusunan proposal sampai sidang akhir riset bulan febuari 2016.

Prosedur pengumpulan data adalah suatu proses pendekatan kepada subjek dan proses pengumpulan krakteristik subjek yang diperlukan dalam suatu penelitian. ${ }^{18}$ Dalam penelitian ini yaitu didapatkan data primer yang diperoleh sendiri sendiri dari pengkajian kepada lansia oleh peneliti, data sekunder yaitu yang di peroleh dari pihak pengelola panti.

Instrumen pengumpulan data adalah alat bantu yang dipilih dan digunakan oleh peneliti dalam kegiatan mengumpulkan data agar kegiatan tersebut menjadi mudah dan sistematik $^{19}$. Alat pengumpulan data dalam penelitian ini yang digunakan peneliti adalah format pengkajian yaitu Mini Mental State Examination (MMSE), yaitu untuk mengukur aspek kognitif tingkat kognitif seperti berikut ini : orientasi, registrasi, perhatian dan kalkulasi serta mengingat dan bahasa. Sedangkan alat untuk mengukur resiko terjadinya jatuh adalah menggunakan format pengkajian keseimbang yaitu untuk mengukur perubahan posisi atau gerakan keseimbangan dan komponen gaya berjalan atau pergerakan pada lansia.

\section{Hasil}

Tabel 1. Distribusi frekuensi responden berdasarkan usia

\begin{tabular}{cccc}
\hline No & Usia & Jumlah & Persentase (\%) \\
\hline 1 & $60-74$ & 23 & 45,0 \\
2 & $75-90$ & 21 & 41,1 \\
3 & $>90 \mathrm{t}$ & 7 & 13,7 \\
\hline \multicolumn{2}{l}{ Jumlah } & 51 & 100 \\
\hline
\end{tabular}

Berdasarkan tabel diatas distribusi frekuensi lansia berdasarkan usia responden terbanyak ditemukan pada lansia dengan usia rata-rata 60-74 tahun.

Tabel 2. Distribusi frekuensi responden berdasarkan jenis kelamin

\begin{tabular}{cccc}
\hline No & Jenis kelamin & Jumlah & $\begin{array}{c}\text { Persentase } \\
(\boldsymbol{\%})\end{array}$ \\
\hline 1 & Laki-laki & 23 & 37,0 \\
2 & Perempuan & 28 & 63,0 \\
\hline & Jumlah & 51 & 100 \\
\hline
\end{tabular}

Distribusi frekuensi responden lansia berdasarkan jenis kelamin didapatkan sebagian besar terdapat pada lansia dengan berjenis kelamin perempuan.

Tabel 3. Distribusi frekuensi responden berdasarkan gangguan kognitif

\begin{tabular}{llcc}
\hline No & Gangguan Kognitif & Jumlah & $\begin{array}{c}\text { Persentase } \\
(\mathbf{\%})\end{array}$ \\
\hline 1 & $\begin{array}{l}\text { Asfek kognitif fungsi } \\
\text { mental sedang }\end{array}$ & 24 & 47,0 \\
2 & $\begin{array}{l}\text { Kesusakan asfek } \\
\text { kognitif mental berat }\end{array}$ & 27 & 52,9 \\
\hline & Jumlah & 51 & 100 \\
\hline
\end{tabular}

Dari tabel distribusi frekuensi responden lansia berdasarkan gangguan kognitif didapatkan paling banyak terjadi pada lansia yang mengalami kerusakan asfek kognitif mental berat. 
Tabel 4. Distribusi Frekuensi Terjadinya Jatuh

\begin{tabular}{llcc}
\hline No & Terjadinya Jatuh & Jumlah & $\begin{array}{c}\text { Persentase } \\
(\%)\end{array}$ \\
\hline 1 & Resiko jatuh rendah & 20 & 39,2 \\
2 & Resiko jatuh sedang & 16 & 31,3 \\
3 & Resiko jatuh tinggi & 15 & 29,4 \\
\hline & J u m l a h & 51 & 100 \\
\hline
\end{tabular}

Berdasarkan table diatas distribusi frekuensi responden lansia yang didapatkan berdasarkan hasil pengumpulan data setelah pengkajian kepada responden yang telah menjadi kriteria penelitian, maka didapatkan perhitungan data berdasarkan jumlah responden yang dikaji, didapatkan resiko jatuh ditemukan terbanyak adalah pada lansia dengan resiko jatuh rendah yaitu dengan jumlah responden lansia pada resiko jatuh tertinggi pada resiko jatuh rendah.

Tabel 5. Hasil Analisa Bivariat Hubungan Gangguan Kognitif Terhadap Resiko Terjadinya Jatuh.

\begin{tabular}{|c|c|c|c|c|c|c|c|c|c|c|}
\hline \multirow{3}{*}{ No } & \multirow{3}{*}{$\begin{array}{c}\text { Gangguan } \\
\text { kognitif }\end{array}$} & \multicolumn{6}{|c|}{ Terjadinya Resiko Jatuh } & \multirow{2}{*}{\multicolumn{2}{|c|}{ Total }} & \multirow{3}{*}{$P$ value } \\
\hline & & \multicolumn{2}{|c|}{ Rendah } & \multicolumn{2}{|c|}{ Sedang } & \multicolumn{2}{|c|}{ Tinggi } & & & \\
\hline & & $\mathbf{n}$ & $\%$ & $\mathbf{n}$ & $\%$ & $\mathbf{N}$ & $\%$ & $\mathbf{N}$ & $\%$ & \\
\hline 1 & Asfek kognitif Sedang & 12 & 23,5 & 7 & 13,7 & 5 & 9,8 & 24 & 100 & \multirow[b]{2}{*}{0,05} \\
\hline 2 & $\begin{array}{l}\text { Kerusakan kognitif } \\
\text { mental Berat }\end{array}$ & 8 & 15,6 & 9 & 17,6 & 10 & 19,6 & 27 & 100 & \\
\hline & Jumlah & 20 & 39,2 & 16 & 31,3 & 15 & 29,4 & 51 & 100 & \\
\hline
\end{tabular}

Dari analisa bivariat menunjukan bahwa hubungan gangguan kognitif terhadap resiko terjadinya jatuh pada lansia ada hubungan yang erat antara gangguan kognitif dan resiko terjadinya jatuh pada lansia. Bahwa proporsi responden dengan resiko terjadinya jatuh yang tinggi lebih banyak pada responden dengan gangguan kognitif yang berat yaitu $19,6 \%$ atau 10 lansia. Hasil uji korelasi diperoleh nilai sig = 907 maka ada hubungan yang erat antara gangguan kognitif terhadap resiko jatuh.

\section{Pembahasan}

\section{Distribusi Frekuensi Responden Berdasarkan Usia.}

Berdasarkan distribusi frekwensi responden berdasarkan usia di panti sosial tresna werdha budi mulya margaguna jakarta. Yang telah di lakukan pada semua responden menunjukan bahwa hasil penelitian proporsi usia lansia lebih banyak pada kelompok lanjut usia (elderly) 60 - 74 tahun. Batasan usia lanjut yaitu usia pertengahan (middle age) usia dari 45-59 tahun, lanjut usia (elderly) usia 6074 tahun, lanjut usia tua (old) usia 76-90 tahun, dan usia lanjut tua (very old) usia diatas 90 tahun. ${ }^{2}$. Menurut Badan Pusat Stastistik Provinsi Riau kelompok usia lanjut "elderly" dengan rentang umur 60-74 tahun di Kota Pekan Baru berjumlah 31.378 orang. Sedangkan yang berusia lebih dari 75 tahun berjumlah 5.237 orang. Fungsi kognitif otak diyakini mulai berkurang saat seorang memasuki usia 60 tahun. ${ }^{20}$ Teori ini didukung oleh pendapat Ari, RK. penurunan fungsi kognitif terbesar terjadi pada responden wanita berusia 65-70 tahun, yaitu sebesar 9,5 \%. ${ }^{21}$ Dari hasil pembahasan diatas, maka krakteristik resonden yang mengalami masalah gangguan kognitif dan beresiko jatuh sebagian besar dapat di pengaruhi oleh usia seseorang lansia.

\section{Distribusi Frekuensi Responden Berdasarkan Jenis Kelamin.}

Berdasarkan hasil penelitian yang telah di lakukan pada semua responden di Panti Sosial Tresna Werdha Budi Mulya Margaguna Jakarta di dapatkan hasil penelitian bahwa sebagian besar responden berjenis kelamin perempuan. Perbedaan proporsi ini dikarenakan responden perempuan lebih banyak di jumpai dari pada laki-laki, sehingga 
kesempatan lansia perempuan untuk dijadikan sebagai responden lebih besar dibandingkan lansia laki-laki. Faktor-faktor yang mempengaruhi fungsi kognitif seseorang adalah usia, jenis kelamin, pendidikan dan status sosial budaya, kondisi psikososial, lingkungan dan pekerjaan. ${ }^{22}$ Myers menyatakan pendapatnya bahwa wanita lebih beresiko mengalami penurunan kognitif dari pada laki-laki. Hal ini disebabkan adanya peranan level hormon seks endogen dalam perubahan fungsi kognitif. ${ }^{23}$ Hasil penelitian ini hampir sama dengan penelitian yang dilakukan oleh Hesti yang meneliti tentang pengaruh gangguan kognitif terhadap gangguan keseimbangan pada lanjut usia yang meneliti 84 orang lansia, dengan hasil penelitiannya yaitu proporsi jenis kelamin responden terdiri dari $75 \%$ wanita dan $25 \%$ pria bahwa sebagian besar $(55,7 \%)$ responden berjenis kelamin perempuan sedangkan sisanya $(44,3 \%)$ adalah lansia pria. $^{24}$ Berdasarkan distribusi responden pada lansia yang dikaji bahwa sebagian besar responden didapatkan berjenis kelamin perempuan.

\section{Distribusi Frekuensi Responden Berdasarkan Gangguan Kognitif.}

Penelitian yang dilakukan terhadap semua responden diperoleh hasil bahwa lansia yang mengalami gangguan fungsi kognitif sebagian besar responden lansia berada pada kategori fungsi kognitif berat, yaitu sebanyak 27 orang responden $(52,9 \%)$. Kognitif adalah aktivitas fisik dan mental yang diformulasikan dengan kemampuan berfikir, mengingat, belajar, dan bahasa yang merupakan proses kerja otak terdiri dari atensi, memori, visiospatial, bahasa, dan fungsi eksekutif.

Gangguan kognitif termasuk demensia pada lansia meningkat sejalan bertambahnya usia, kurang dari 3\% terjadi pada kelompok usia 65-70 tahun dan lebih dari $25 \%$ terjadi pada kelompok usia 85 tahun ke atas. Salah satu masalah kesehatan pada lansia yaitu gangguan kognitif. Adapun faktor penyebab gangguan kognitif adalah kelainan di bagian anatomi otak akibat proses penuaan sehingga dapat mempengaruhi proses kognitif. Lansia yang mengalami penurunan fungsi -fungsi otak sesuai dengan bertambahnya umur dan sel otak akan mengecil (atrofi) sehingga fungsinya menurun dalam rangkaian sistem, sehingga dapat menimbulkan kelainan misalnya seperti kelainan presepsi, perhatian, bahasa, memori, emosi dan fungsi eksekutif. Gejalanya antara lain, disorientasi, gangguan bahasa (afasia), penderita mudah bingung, penurunan fungsi memori lebih berat sehingga lansia tidak dapat melakukan kegiatan sampai selesai, tidak mengenal anggota keluarganya dan tidak dapat mengingat tindakan yang sudah dilakukan sehingga dapat mengulangi nya lagi. Selain itu penderita dapat mengalami gangguan visuospasial, menyebabkan penderita mudah tersesat di lingkungannya. Hal ini diperberat dengan kondisi lansia yang mengalami kemunduran kapasitas fisiologis, misalnya kekuatan otot, kapasitas aerobik, koordinasi neuromotorik, dan fleksibilitas sehingga lansia tersebut memiliki risiko terhadap cedera seperti terjatuh saat melakukan aktivitas fisik yang terbatas. Gangguan kognitif pada lansia berhubungan erat dengan lokasi kelainan di bagian anatomi otak. Masing-masing memiliki fungsi anatomi yang dapat mempengaruhi proses kognitif. .

Hasil penelitian ini hampir sama dengan penelitian yang dilakukan oleh Dongoran yang melakukan penelitian tentang Hubungan Antara Arterioskeloris Retina Dengan Fungsi Kognitif Pada Penderita Hipertensi yang mengatakan bahwa 11 orang responden dengan gangguan fungsi kognitif sedangkan 50 responden lainnya tanpa ada gangguan fungsi kognitif. ${ }^{25}$ Menurut hasil yang ditemukan dalam penelitian ini bahwa lansia yang mengalami masalah gangguan kognitif berat lebih banyak hal ini dipicu dengan adannya beberapa faktor yang mempengaruhi seorang lansia yang mengalami masalah gangguan kognitif diantaranya adalah seperti kelainan dibagian anatomi otak akibat proses penuaan maka otak akan mengalami pengecilan (atrofi) sehingga menimbulkan kelainan seperti perubahan presepsi, perhatian, bahasa, memori, emosi dan fungsi eksekutif.

\section{Distribusi Frekuensi Responden Berdasarkan Resiko Jatuh}

Hasil penelitian pada lansia dengan masalah resiko jatuh didapatkan bahwa proporsi resiko jatuh responden lebih banyak pada kategori rendah. Jatuh merupakan salah satu kejadian yang dilaporkan penderita atau saksi mata yang melihat kejadian yang mengakibatkan seseorang mendadak terbaring atau terduduk dilantai atau ditempat yang lebih rendah dengan atau tanpa kehilangan kesadaran atau luka. Faktor penyebab jatuh diantaranya adalah faktor intrinsik seperti gangguan gaya berjalan, kelemahan otot 
ekstremitas bawah, kekakuan sendi, sedangkan faktor ekstrinsik seperti lantai yang licin dan tidak rata, tersandung benda-benda, penglihatan yang kurang jelas akibat cahaya yang kurang terang. ${ }^{21}$ Pada usia lanjut terjadi perubahan pada sîstim sensorik, muskuloskeletal, dan sistim saraf pusat, Sistem Muskuloskeletal yang merupakan komponen struktural utama mengalami perubahan dalam muskular, yaitu otot mengecil secara progresif (atrofi) dan tulang kehilangan kalsium secara progresif atau dekalsifikasi. Perubahan yang seiring dengan pertambahan usia tersebut memberi sumbangan bagi berkurangnya kontrol keseimbangan pada pasien lanjut usia yang selanjutnya menyebabkan lansia beresiko mengalami injury. ${ }^{24}$

Menurut penelitian Reuben dkk, mendapatkan insiden jatuh dimasyarakat AS lebih dari 65 tahun berkisar $1 / 3$ populasai lansia setiap tahun dengan rata-rata jatuh 0,6 per orang insden dirumah 3 kali ebih banyak 5\% dari penderita jatuh ini mengalami patah tulang atau memerlukan perawatan dirumah sakit. ${ }^{26}$ Menurut hasil temuan dalam penelitian ini lansia yang mengalami resiko jatuh disebabkan oleh beberapa faktor diantaranya seperti yang dialami lansia itu sendiri seperti gangguan gaya berjalan, kelemahan otot, dan juga dipengaruhi seperti faktor ruangan yg gelap, lantai yang licin dan tinggi. Hubungan Gangguan Kognitif Pada Lansia dengan Resiko Terjadinya Jatuh Pada Lansia.

\section{Hubungan Gangguan Kognitif dengan Resiko Jatuh Pada Lansia}

Hasil penelitian yang didapatkan berdasarkan analisa pengumpulan data lansia pada masalah gangguan kognitif mental berat pada resiko jatuh tinggi lebih banyak. Hasil uji (korelasi) diperoleh nilai sig $=907$ yang berarti bahwa ada hubungan yang erat antara gangguan kognitif dan resiko terjadinya jatuh pada lansia. Hasil penelitian telah membuktikan hipotesis penelitian bahwa ada hubungan antara gangguan kognitif dengan resiko terjadinya jatuh pada lansia. Menurut Depkes bahwa lansia yang mengalami gangguan kognitif awalnya ditemukan gejala mudah lupa berlanjut dengan kesulitan mengenal benda dan akhirnya tidak mampu menggunakan barang-barang sekalipun yang termudah. sehingga lansia tersebut memiliki risiko terhadap cedera seperti terjatuh saat melakukan aktivitas fisik yang terbatas. Lansia yang mengalami gangguan kognitif awalnya ditemukan gejala mudah lupa berlanjut dengan kesulitan mengenal benda dan akhirnya tidak mampu menggunakan barang-barang sekalipun yang termudah. Selain itu lansia dapat mengalami gangguan visuospasial, menyebabkan lansia mudah tersesat di lingkungannya dan dengan kondisi lansia yang mengalami kemunduran kapasitas fisiologis, misalnya kekuatan otot, kapasitas aerobik, koordinasi neuromotorik, dan fleksibilitas sehingga lansia tersebut memiliki risiko terhadap cedera seperti terjatuh saat melakukan aktivitas fisik yang terbatas. ${ }^{5}$

Hal ini sesuai dengan yang dikemukakan Hesti bahwa salah satu aspek kognitif yaitu perhatian atau atensi. Yang mempunyaî peranan penting dalam keseimbangan pada lansia, dan atensi makin dibutuhkan pada keadaan - keadaan yang menyebabkan penurunan keseîrnbangan dan peningkatan risiko jatuh pada lansia. ${ }^{24}$ Hasil penelitian ini di dukung oleh penelitian yang dilakukan oleh Pinandita tentang hubungan antara pengetahuan dengan sikap lansia penderita osteoporosis dalam upaya pencegahan jatuh di rumah di Puskesmas Kartasura yang mendapatkan hasil bahwa terdapat hubungan yang signifikan tingkat pengetahuan lanjut usia tentang pencegahan jatuh dengan sikap lanjut usia dalam mencegah jatuh pada lanjut usia di puskesmas kartasura ( $\chi 2$ hitung $=6,099$ dan $p$-value $=0,014) .{ }^{27}$

Berdasarkan hasil penelitian tersebut disarankan pada lanjut usia untuk berhati-hati dalam melaksanakan aktifitas di rumah dan menghindari segala hal yang dapat menyebabkan jatuh. Hasil penelitian ini juga sesuai dengan penelitian yang dilakukan oleh Nurrohmah (2009) tentang Hubungan Antara Gangguan Gerak Dan Fungsi Kognitif Pada Wanita Lanjut Usia Di Panti Wredha Surakarta yang meneliti 36 responden lansia dan memperoleh hasil bahwa adanya hubungan antara gangguan gerak dan fungsi kognitif dengan nilai signifikansinya sebesar $(0,000<0,05) .{ }^{28}$ Hasil penelitian ini berbeda dengan penelitian yang dilakukan oleh Suyanto yang melakukan penelitian tentang faktorfaktor yang berhubungan dengan kejadian jatuh/falls pada lansia di Panti Wredha Pucang Gading Semarang pada 30 responden yang menyatakan bahwa ada hubungan antara gangguan gaya berjalan dengan kejadian jatuh $(\mathrm{p}=0,048)$, tidak ada hubungan antara demensia dengan kejadian jatuh $(\mathrm{p}=0,593)$. Dengan demikian lansia yang mengalami 
gangguan kognitif beresiko cedera jatuh. Hal ini perlu dilakukan intervensi-intervensi yang dapat memelihara dan meningkatkan kemampuan kognitif lansia tersebut. Intervensi tersebut seperti upaya prevensi primer dengan melakukan penyuluhan kesehatan serta konseling kesehatan lansia, serta upaya prevensi sekunder yaitu melakukan deteksi dini pada lansia yang beresiko jatuh.

\section{Kesimpulan}

Penelitian ini telah mengidentifikasi beberapa karakteristik dari semua lansia yang mengalami gangguan kognitif dan resiko jatuh di Panti Sosial Tresna Werdha Budi Mulya Margaguna Jakarta. Dari hasil penelitian yang telah dilakukan dapat diambil kesimpulan yaitu: Karakteristik lansia yaitu lebih banyak lansia pada kelompok usia 60-74 tahun dan jenis kelamin lansia lebih banyak adalah perempuan. Distribusi frekuensi responden lansia yang mengalami masalah gangguan kognitif terbanyak ditemukan pada lansia dengan kerusakan asfek kognitif mental berat. Proporsi lansia yang mengalami resiko terjadinya jatuh lebih banyak pada kategori rendah. Jadi berdasarkan hasil penelitian tersebut dapat disimpulkan hubungan gangguan kognitif terhadap resiko terjadinya jatuh pada lansia.

\section{Saran}

Bagi profesi keperawatan hasil peneliti ini dapat digunakan sebagai dasar dan pedoman untuk melaksanakan penelitian lebih lanjut yang komperhensif dengan tindakan keperawatan yang berbeda. Bagi lansia hasil penelitian ini dapat memberikan pengetahuan bagi lansia yang mengalami kognitif agar dapat memanfaatkan aktivitas sehari-hari untuk terus belajar dan aktif mengikuti kegiatan lansia.

Bagi institusi Sebagai masukan untuk meningkatkan mutu pelayanan terhadap lansialansia dipanti yang berkaitan tersebut. Manfaat metodologi Sebagai sumbangan pemikiran bagi peneliti lain untuk melakukan penelitian lebih lanjut yang terkait dengan faktir lain yang berhubungan dengan analisa faktor gangguan kognitif terhadap resiko terjadinya jatuh pada lansia.

Bagi peneliti selanjutnya diharapkan peneliti yang akan datang supaya dapat meningkatkan kemampuan kognitif lansia seperti metode brain gym dengan asfek-asfek yang lebih rinci lagi mengenai faktor-faktor gangguan kognitif yang berhubungan dengan penurunan fungsi kognitif pada lansia.

\section{Daftar Pustaka}

1. Azizah, LM. Keperawatan Lanjut Usia. Yogyakarta: Graha Ilmu; 2011.

2. Bandiyah, Buku Ajar Keperawatan Lanjut Usia Jakarta : Salemba Medika; 2009.

3. Noorkasiani, Kesehatan Usia Lanjut dengan Pendekatan Asuhan Keperawatan. Jakarta : Salemba Medika ; 2009.

4. Nur, Hubungan Antara Gangguan Gerak Dan Fungsi Kognitif Pada Wanita Lanjut Usia. Surakarta ; 2009.

5. Depkes RI, Keputusan Menteri Kesehatan RI tentang Pedoman Rehabilitasi Kognitif. Jakarta ; 2010. Diperoleh dari http://Kognitif.pdf. pada tanggal 3 Desember 2011.

6. Ravagia, Gangguan Kognitif Ringan. Jurnal Ilmiah Kesehatan Keperawatan, [Online]dari http:diglib.stikesmuhgombong.ac.id diakses 20 maret 2008.

7. Rosdiana, Gambaran Tingkat Kognitif dan Fungsi Kognitif Pada Lansia. Universitas Airlangga;2009.

8. Silviani, Hubungan Gangguan Kognitif terhadap Terjadinya Injuri Pada Lansia. Universitas muhammadiyah; Jakarta ; 2013.

9. Maryam, Keperawatan Lanjut Usia. Jakarta : Salemba Medika; 2011.

10. Purba JS, Demensia dan Penyakit Alzheimer.Jakarta : BP FKUI; 2006

11. Prihartono, Pengaruh Gangguan Kognitif Terhadap Gangguan Keseimbangan Usia Lanjut,DDST-II 2008.[Online] dari http://etd.eprints.ums.ac.id/10363/J110050000 5.pdf pada tanggal 3 Desember 2011.

12. Johnson, Terapi Akitivitas Kelompok Reminiscence.Jakarta : Gramedia; 2005.

13. Tammase, Tehnik Brain Gym. Jurnal Ilmiah Kesehatan Keperawatan. Jakarta: BP FKUI; 2009.

14. Setyopranoto, Penilaian Mini Mental State Examination (MMSE) pada Penderita Stroke Iskhemik Akut di RSUP Dr.Sardjito. Yogyakarta: 2006.

15. Depkes RI, Pedoman Kesehatan Usia Lanjut. Jakarta: Ditjen Binkesmas;2009.

16. Notoatmodjo, Metodologi Penelitian Kesehatan. Jakarta : Rineka Cipta; 2010.

17. Setiadi, Metode Penelitian. Jakarta : EGC ; 2007. 
18. Nursalam, Metodologi Penelitian Ilmu Keperawatan ( Pendekatan Praktis). Jakarta : Salemba Medika ; 2008.

19. Arikunto, Prosedur Penelitian Suatu Pendekatan Praktek edisi Revisi VI. Jakarta : Rineka Cipta ; 2006.

20. Badan Stastistik, Kelompok Usia Lanjut. Jakarta : 2013.

21. Ari, RK. Penurunan Fungsi Kognitif. di perolehdari http://ketutpsik08.wordpress.com :2013.

22. Lisnaini, Faktor - factor Mempengaruhi Fungsi Kognitif. Jakarta ; 2012.

23. Myers, Resiko Penurunan Fungsi Kognitif. Bandung ; Rineka Cipta ; 2008.

24. Hesti, ddk. Pengaruh Gangguan Kognitif Pada Keseimbangan. Yogyakarta;2007.

25. Dongoran, Hubungan Antara Arterioskeloris Retina Dengan Fungsi
KognitifPadaPenderitaHipertensi.http://eprints .undip.ac.id/16907/1/Daniel_Naek_Hatuaon_D ongoran.pdf: 2007.

26. Ruben, ddk. Insiden Jatuh. Diperoleh dari https;//pdf pada tanggal 3 desember 2006.

27. Pinandita, hubungan antara pengetahuan sikap lansia pada penderita osteoporosis dalam upaya pencegahan jatuh. Bandung: Alfabeta. 2011.

28. Nurrohmah, (Hubungan Antara Gangguan Gerak Dan Fungsi Kognitif Pada Wanita Lanjut Usia Di Panti Wredha Surakarta ; 2009 di peroleh. dari http://etd.eprints.ums.ac.id /10363/1/J110050005. pdf pada tanggal 3 Desember 2011.

29. Suryanto, Faktor-factor yang berhubungan jatuh/falls. Semarang : Rineka Cipta ; 2008. 